\title{
THE EFFECT OF FREELETIC EXERCISE ON LEG STRENGTH IN FREELETIC COMMUNITY
}

\author{
Hastuti $^{1}$, Irianto ${ }^{1}$, Bustaman Wahab ${ }^{2}$ \\ ${ }^{1}$ Physiotherapy Study Program, Faculty of Nursing, Hasanuddin University, Makassar \\ ${ }^{2}$ Department of Physical Medicine and Rehabilitation, Wahidin Sudirohusodo Hospital, Makassar
}

Correspondence author:

Irianto

Physiotherapy Study Program, Faculty of Nursing, Hasanuddin University Makassar Email: iriantokadir91@gmail.com

\section{Article Info:}

Received: 31 May 2018

Revised: 05 June 2018

Accepted: 30 June 2018

Available online: 31 December 2018

Keywords: Leg Muscle Strength, Freeletic Community, Freeletic Sport

DOI: $10.20956 /$ mmsj.v3i1.5773

\begin{abstract}
Introduction: Any human exercise will always involve physical conditions in it. there are 10 kinds of components of physical condition, that is strength, endurance, muscle power, speed, flexibility, agility, coordination, balance, accuracy, and reaction. Limb muscles play a leading role in many sports. To improve and develop the physical condition of an athlete, it takes an exercise, an exercise that someone has to do continuously in order to produce maximum movement. Freeletic exercise is one of the techniques used to increase leg muscle strength. This study aims to determine differences in leg muscle strength in freeletic members before and after the provision of freeletic exercise.

Methods: This study is Pre Exsperimental and using one group pre-post test design. The sampling technique is purposive sampling with the number of samples is 20 people based on the inclusion and exclusion criteria for 6 weeks. Measuring tool used is Leg Dynamometer and Squat Test to know the value of muscle strength of limb before and after 18 sessions. Results: The results showed that freeletic sport training increased leg muscle strength of the respondents.
\end{abstract}

\section{Pendahuluan}

Otot tungkai memegang peranan utama keberhasilan dalam berbagai cabang olahraga. Untuk meningkatkan kemampuan dan mengembangkan kondisi fisik seorang atlet, dibutuhkan sebuah latihan, latihan yang secara terus-menerus agar menghasilkan gerakan yang maksimal. ${ }^{1}$ Salah satu tempat olahraga yang dapat meningkatkan kekuatan otot tungkai adalah komunitas Freeletic. Dimana, latihan-latihan dalam komunitas ini diberi nama olahraga freeletic sesuai dengan nama komunitasnya. Olahraga freeletic merupakan aktivitas olahraga terbaru yang sekarang mulai berkembang diseluruh dunia. Bentuk olahraga dari Freeleticss adalah gabungan dari body weight training (latihan beban tanpa beban tambahan dan hanya

menggunakan berat badan sendiri) dan high intensity interval training (kombinasi antara latihan intensitas tinggi dengan intensitas sedang atau rendah dalam selang waktu tertentu) yang membuat pembakaran lemak menjadi lebih optimal. Salah satu latihan di Freeleticss adalah latihan strength untuk meningkatkan muscle strength. Gerakan-gerakan yang dilakukan pada Freeletic ini tergolong mudah tetapi semakin lama akan semakin berat dan rutin dilakukan tiga kali seminggu. ${ }^{4}$ Latihan beban adalah latihan yang sistematis yang menggunakan beban 
sebagai alat untuk menambah kekuatan otot guna mencapai tujuan. ${ }^{3}$ Pada dasarnya body weight training sama dengan weight training, tetapi dibedakan dengan model latihan dan variasi latihan yang berbeda. Penelitian terdahulu tentang Rope jump dengan metode interval training terhadap kekuatan otot tungkai menyatakan bahwa latihan interval adalah yang diselingi antara pemberian beban latihan dengan waktu istirahat. Dalam latihan interval bisa dilakukan dengan intensitas tinggi maupun intensitas rendah tergantung dari kebutuhan kondisi fisik yang di inginkan. Latihan fisik yang diulang-ulang dengan diselingi waktu atau periode-periode pemulihan. Latihan interval intensitas tinggi dapat didefinisikan sebagai bentuk lomba-lomba atau gerakan pendek pada latihan yang dilakukan secara intense dan intervals pada latihan intensitas rendah sebagai recovery dari interval tersebut. Berdasarkan hasil penelitian tersebut, bila diterapkan secara teratur, terprogram, berkesinambungan, serta disiplin yang tinggi terbukti dapat meningkatkan kekuatan otot tungkai. Dari hasil observasi yang peneliti lakukan di komunitas freeletic Makassar, mendapatkan hasil bahwa orang-orang yang tergabung di komunitas ini adalah orang-orang yang memiliki keinginan untuk hidup lebih sehat dan ingin menjadikan suatu olahraga itu bukan lagi hanya sebatas keinginan semata, melainkan menjadikan olahraga adalah suatu kebutuhan. Komunitas freeletic ini dibangun sebagai sarana untuk masyarakat umum yang ingin menjalani pola hidup sehat dengan berolahraga.. Maka dari itu, peneliti ingin melihat pengaruh olahraga freeletic terhadap tingkat kekuatan otot tungkai komunitas

$$
\text { freeletic }
$$

Makassar.

\section{METODE}

Penelitian ini dilaksanakan di Komunitas Freeletic Makassar. Penelitian ini dilakukan

dengan menggunakan desain penelitian pra eksperimen dengan rancangan One-group pre-post test design. Kelompok subjek diobservasi sebelum dilakukan intervensi (pre test), kemudian diobservasi lagi setelah intervensi (post test). Populasi dalam penelitian ini adalah seluruh anggota freeletic Makassar. Sampel penelitian ini berjumlah 20 orang yang diperoleh dari populasi penelitian yang memenuhi kriteria inklusi yang ditetapkan peneliti. Berjenis kelamin laki-laki. anggota berumur 20-30 tahun, anggota yang dapat memahami dan mampu melaksanakan prosedur penelitian, dan anggota bersedia menjadi sampel penelitian Data yang terkumpul dilakukan uji paired sample test. Namun sebelum dilkaukan uji-t maka dilakukan terlebih dahulu uji normalitas untuk memenuhi syarat uji-t yakni data bersebaran normal menggunakan uji saphiro-wilk. Analisis data menggunakan paket SPSS 22.0 for windows, serta disajikan dalam bentuk tabel dan narasi.

\section{HASIL}

Tabel 2 menunjukkan pada saat pre test kekuatan otot tungkai dengan menggunakan leg dynamometer, sebanyak 12 orang $(60 \%)$ yang memiliki kategori sedang dan 8 orang (40\%) yang memiliki kategori kurang. Pada post test sampel secara keseluruhan berada pada kategori sedang sebanyak 20 orang (100\%). Hasil uji t berpasangan pada kekuatan otot tungkai dengan menggunakan leg dynamometer diperoleh nilai $\mathrm{p}$ $=0.000$ dimana $\mathrm{p}<0,05$. Hal ini berarti hipotesis penelitian diterima bahwa terdapat pengaruh olahraga freeletic terhadap peningkatan kekuatan otot tungkai pada anggota freeletic Makassar.

\section{Tabel Karakteristik Sampel}

\begin{tabular}{ccc}
\hline Karakteristik Sampel & $\mathrm{N}$ & $\%$ \\
\hline Umur & & \\
\hline $20-25$ & 10 & 50 \\
$26-31$ & 10 & 50 \\
\hline Total & 20 & 100 \\
\hline IMT & &
\end{tabular}




\begin{tabular}{|c|c|c|}
\hline Underweight $(<18,5)$ & 0 & 0 \\
\hline Normal $(18,5-24,9)$ & 16 & 80 \\
\hline Overweight $(25,0-29,9)$ & 4 & 20 \\
\hline Total & 20 & 100 \\
\hline \multicolumn{3}{|l|}{ Pekerjaan } \\
\hline Buruh harian & 1 & 5 \\
\hline Dinas perhubungan & 1 & 5 \\
\hline Karyawan swasta & 2 & 10 \\
\hline Mahasiswa & 9 & 45 \\
\hline Pegawai bank & 1 & 5 \\
\hline Wiraswasta & 6 & 30 \\
\hline Total & 20 & 100 \\
\hline \multicolumn{3}{|l|}{ Aktivitas lain } \\
\hline Tidak ada & 12 & 60 \\
\hline Lari & 6 & 30 \\
\hline Futsal & 2 & 10 \\
\hline Total & 20 & 100 \\
\hline
\end{tabular}

2.Tabel hasil kategori pre-test dan post-test leg dynamometer

\begin{tabular}{|c|c|c|c|c|}
\hline \multirow{3}{*}{ Kategori } & \multicolumn{4}{|c|}{ Leg dynamometer } \\
\hline & \multicolumn{2}{|c|}{ Pre Test } & \multicolumn{2}{|c|}{ Post Test } \\
\hline & $N$ & $\%$ & $n$ & $\%$ \\
\hline Baik Sekali & 0 & & 0 & 0 \\
\hline Baik & 0 & & 0 & 0 \\
\hline Sedang & 12 & 60 & 20 & 100 \\
\hline Kurang & 8 & 40 & 0 & 0 \\
\hline Kurang Sekali & 0 & & 0 & 0 \\
\hline
\end{tabular}


3.Tabel analisis data pre-test dan post-test leg dynamometer

\begin{tabular}{cccc}
\hline & Rata- Rata & SD \pm & $P$ \\
\hline Pre Test & 132.05 & 28.294 & 0.000 \\
Post Test & 160.80 & 30.624 &
\end{tabular}

\section{PEMBAHASAN}

Dari hasil penelitian menunjukkan bahwa terdapat perubahan yang signifikan terkait tingkat kekuatan otot tungkai dengan pemberian latihan olahraga freeletic pada anggota freeletic Makassar. Olahraga freeletic ini terdiri dari 7 sirkuit yang dimana, tiap sirkuit terdiri dari 3 gerakan. Jadi, secara keseluruhan, latihan olahraga freeletic terdiri dari 21 gerakan yang dilakukan selama kurang lebih 40 - 60 menit. Seperti yang kita ketahui bahwa olahraga freeletic ini merupakan olahraga yang menggabungkan antara body weight training dengan high intensity interval training yang menggunakan sistem circuit training.

Sejalan dengan penelitian sebelumnya yang menyatakan bahwa pelatihan high intensity interval training akan meningkatkan ambang laktat maupun ambang anaerobik atlet melalui beberapa mekanisme, yaitu terjadi peningkatan kekuatan otot dengan cara mengurangi peran otot skeletal tipe I dan mengurangi oklusi pada aliran darah. Latihan dengan metode ini dapat meningkatkan perkembangan serabut otot cepat untuk meningkatkan memori otot. High intensity interval training merupakan metode pelatihan yang ampuh dan hemat waktu untuk menginduksi baik adaptasi pusat (kardiovaskular) maupun adaptasi perifer (otot rangka) adaptasi yang terkait dengan peningkatan kesehatan.

Terdapat pengaruh yang signifikan latihan squat dan leg press terhadap peningkatan strength dan hypertrophy otot tungkai. ${ }^{1}$ Squat merupakan latihan dasar dari olahraga freeletic yang merupakan body weight training untuk meningkatkan, menguatkan, mengembangkan kekuatan otot pada tungkai. Selain itu ada pula beberapa gerakan penguatan otot tungkai seperti High jump, lunges, kick squat, side lunges, flying climber, kick lunges, reverse lunges high knee, dan squat jump. Latihan - latihan tersebut mengatifkan kerja dari otot quadriceps, hamstring, glutea, gastricnemius, soleus dan otot tungkai lainnya.

Weight training merupakan latihan yang memberikan pembebanan terhadap otot. Selama

latihan, otot-otot tubuh khususnya otot tungkai terlibat dalam gerakan melawan beban yang dilakukan secara berulang-ulang. ${ }^{2}$ Pada latihan beban ini prinsip overload sangat terlihat dimana penggunaan beban berlebih akan menyebabkan terjadinya proses adaptasi fisiologis yang akan mengarahkan pada peningkatan kekuatan otot. Terjadinya perubahan peningkatan kekuatan otot tungkai ini disebabkan karena tubuh telah mengalami adaptasi terhadap olahraga yang diberikan. Sebagai akibat dari bertambahnya myofibril pada setiap serabut otot, meningkatnya densitas (kepadatan) kapiler pada setiap serabut otot, meningkatnya jumlah protein, dan bertambah jumlah serabut otot. Peningkatan kekuatan otot ini terjadi akibat adanya hypertrophy (pembesaran) otot. Otot yang terlatih dapat menjadi lebih besar, sehingga

kekuatan otot pun akan meningkat.

\section{KESIMPULAN}

Berdasarkan hasil dan pembahasan tentang pengaruh pemberian latihan olahraga freeletic terhadap peningkatan kekuatan otot tungkai dengan nilai $\mathrm{p}=0,000$ maka dapat disimpulkan bahwa ada pengaruh yang signifikan latihan olahraga freeletic terhadap peningkatan kekuatan otot tungkai pada anggota freeletic di Komunitas Freeletic Makassar. Bagi responden, melakukan olahraga freeletic di Komunitas Freeletic Makassar sebagai upaya peningkatan kekuatan otot tungkai yang juga akan meningkatkan kemampuan fisik dan kebugaran jasmani. Bagi pelatih, agar untuk memberikan program latihan olahraga freeletic kepada seluruh anggota freeletic sebagai upaya peningkatan 
kekuatan otot tungkai yang juga akan membantu orang-orang yang ingin memiliki tubuh yang sehat dan penguatan otot dengan olahraga. Bagi fisioterapis, hasil dari penelitian ini dapat menjadi data dasar bagi pengembangan pelayanan fisioterapi khususnya fisioterapi olahraga, dalam memberikan jenis latihan

\section{DAFTAR PUSTAKA}

1. Rachman, Aryadi. Pengaruh Latihan Squat Dan Leg Press Terhadap Strength Dan Hypertrophy Otot Tungkai. Kota Banjarbaru; 2014.

2. Sucipto, Eko. Pengaruh Latihan Beban Dan Kekuatan Otot Terhadap Hypertrophy Otot Dan Ketebalan Lemak. Pendidikan penguatan otot tungkai. Bagi peneliti selanjutnya, penelitian ini sebagai masukan dan bahan referensi bagi peneliti selanjutnya yang ingin melanjutkan penelitian terkait penelitian ini agar dapat menjadi pembeda ataupun pelengkap.

Kesehatan dan Rekreasi Universitas Negeri Yogyakarta. Yogyakarta; 2016.

3. Suharjana. Kebugaran Jasmani. Jogja Global Media. Yogyakarta; 2013.

Utami, Eulis. Freeletics Makassar Giatkan Masyarakat Makassar Untuk Hidup Sehat, (Online). 2017. (diakses 7 Januari 2018). From: http://komunita.id 